\title{
A 22-es csapdája? \\ A 22q11 kromoszóma deletiós szindróma változatos klinikai megjelenése két eset kapcsán
}

\author{
Till Ágnes dr. - Hadzsiev Kinga dr. - Lőcsei-Fekete Anett dr. \\ Czakó Márta dr. - Duga Balázs - Melegh Béla dr.
}

Pécsi Tudományegyetem, Általános Orvostudományi Kar, Klinikai Központ, Orvosi Genetikai Intézet, Pécs

\begin{abstract}
A 22q11 deletiós szindróma szerteágazó klinikai tüneteket mutató, általában jellegzetes arcdysmorphiával és többszörös fejlődési rendellenességgel járó tünetegyüttes. A diagnózis megállapítása a jellegzetes tünetek együttállása esetén a mindennapi gyakorlatban célzott in situ fluoreszcens hibridizációs próbával lehetséges. A bemutatásra kerülő két beteget a szerzők több éven keresztül követték genetikai tanácsadójukban minor anomáliák és fejlődési rendellenességek miatt, de a vizsgálatokkal definitív diagnózishoz nem jutottak. A szerző́k intézetében évek óta alkalmazott array komparatív genomhibridizációs módszerrel vizsgálva mindkét betegnél a 22-es kromoszóma hosszú karján a 11.2 régió deletiója igazolódott. A szerzôk a 22q11 kromoszóma deletiós szindróma gyakoriságára, szerteágazó fenotípusos megjelenésére hívják fel a figyelmet, amelynek felderítésében az új molekuláris genetikai módszer lehet segítségre. Orv. Hetil., 2015, 156(45), 1834-1838.
\end{abstract}

Kulcsszavak: 22q11 kromoszóma deletiós szindróma, array-CGH, FISH, arcdysmorphia

\section{Catch-22! Wide variety of phenotypes associated with the chromosome $22 \mathrm{q} 11$ deletion syndrome in two patients}

The chromosome $22 \mathrm{q} 11$ deletion syndrome may present with a variety of phenotypes. Its symptoms generally include a characteristic facial dysmorphisms and multiplex developmental disorders. Fluorescence in situ hybridization is the current method of choice for the diagnosis if typical multiple defects and/or symptoms are present. The authors present the history of two patients who were followed-up for minor anomalies and various developmental disorders for several years in the genetic counseling office of the authors, but definitive diagnosis was not established. However, when DNA samples of the two patients were recently tested with array comparative genome hybridization, a diagnostic method which has already been used in their institute for several years, the results indicated deletion of the 11.2 region on the long arm of chromosome 22 in both patients. The authors draw attention to the incidence and wide phenotypic spectrum of the chromosome $22 \mathrm{q} 11$ deletion syndrome, and show that its identification can be aided with the novel molecular cytogenetic method available in their laboratory.

Keywords: 22q11 deletion syndrome, array-CGH, FISH, facial dysmorphisms

Till, Á., Hadzsiev, K., Löcsei-Fekete, A., Czakó, M., Duga, B., Melegh, B. [Catch-22? Wide variety of phenotypes associated with the chromosome 22q11 deletion syndrome in two patients]. Orv. Hetil., 2015, 156(45), 1834-1838.

(Beérkezett: 2015. augusztus 19.; elfogadva: 2015. szeptember 10.) 


\section{Rövidítések}

aCGH = array komparatív genomhibridizáció; FISH = fluoreszcens in situ hibridizáció; $\mathrm{IgG}=$ immunglobulin $\mathrm{G}$; $\mathrm{TBXI}=$ T-box-containing transcription factor

A 22-es kromoszóma hosszú karjának deletiója nagyon különböző fenotípusmegjelenéssel járhat, mint a klasszikus Di George-szindróma, a velocardiofacialis vagy Shprintzen-szindróma, a Takao-szindróma vagy izolált kiáramlásipálya-defektusok (Fallot-tetralógia, truncus arteriosus, aortaív-interruptio). Napjainkban ezek összefoglaló neve a 22q11 deletiós szindróma. A klinikai megjelenés sokszínűségét és a diagnózis nehézségét kíséreli meg érzékeltetni a korábbi évek irodalmában előforduló CATCH-22 mozaikszó, amely a fó tünetek angol kezdőbetüjének összeolvasásából jön létre (cardiac abnormality/abnormal facies/T-cell deficit due to thymic hypoplasia/cleft palate/hypocalcaemia due to hypoparathyroidism resulting from $22 \mathrm{ql1})$ [1, 2]. A szisztematikus besorolás és pontosság igénye miatt ma a klasszikus 22 q11.2 deletióval rendelkező betegeket a genetikai nómenklatúra szerint ajánlott 22q11.2 deletiós szindróma elnevezéssel illetni. Azoknál a betegeknél azonban, akiknek klinikai fenotípusa megegyezik ugyan, de annak oka más vagy ismeretlen, a szindromatológiai nómenklatúra szerint a Di George-szindróma elnevezést használjuk [1].

A 22q11 deletiós szindróma a leggyakoribb microdeletiós szindróma. Irodalmi adatok alapján 4000 újszülöttből l érintett, bár valószínúleg aluldiagnosztizált. Nők és férfiak egyenlő arányban betegszenek meg, a spanyol származásúak között azonban gyakrabban fordul elő [3]. Az esetek több mint 90\%-ában de novo a deletio, de familiáris esetek is ismertek. Előfordul, hogy felnőttkorban diagnosztizálják a szindrómát olyan diszkrét tüneteket mutató betegekben, akiknek családjában klasszikus fenotípusú gyermek született [4]. A betegség patogenezisének alapját a 22-es kromoszóma q11.2 régiójának instabil, mutációra hajlamos volta képezi. Ez a régió gazdag a kromoszómaspecifikus alacsony kópiaszámú ismétlődésekben, más néven szegmentális duplikációkban. E szakaszok nem megfelelő átrendeződése a nem allélikus homológ rekombináció során vezet az általában 1,5-3 Mb hosszúságú deletióhoz. A klinikai tünetek oka a csökkent génexpresszió, de ennek pontos mechanizmusa még nem teljesen ismert [5]. A leggyakrabban deletálódó $3 \mathrm{Mb}$ hosszúságú régió több mint 35 gént tartalmaz, ezek csökkent génexpressziója valószínúleg a garatívek, a szív, a csontrendszer és az agy korai morfogenezisét befolyásolja. A legtöbbet vizsgált T-box-containing transcription factort (TBXl) kódoló gén egy olyan transzkripciós faktort kódol, amelynek szerteágazó szerepe van az embrionális differenciációban. Irodalmi adatok arra utalnak, hogy nagyrészt a TBXl gén tehető felelőssé a 22q11.2 deletiós szindróma klinikai tüneteinek kialakulásáért, bár a TBXI haploinsufficientia minden klinikai fenotípust nem magyaráz [6].
A 22q11.2 deletiós szindróma fenotípusos megjelenése nagyon változatos, legjellemzőbb klinikai tünetei a következők: jellegzetes arcdysmorphia, veleszületett szívfejlődési rendellenesség, lágyszájpad-elégtelenség hasadékkal vagy a nélkül, thymus-hypoplasia, immundeficientia, mellékpajzsmirigy-hypoplasia, fejlődésbeli elmaradás, tanulási nehézség, pszichiátriai betegségek, vese-, szem- és csontrendszeri malformációk, a gége rendellenességei, halláscsökkenés. A diagnózist praenatalisan, újszülött- és gyermekkorban, illetve felnőttkorban állapítják meg [7]. A 22q11.2 deletiós szindróma jellemző tüneteit az 1. táblázatban foglaltuk össze. A 22q11.2 microdeletio kimutatása a mindennapi gyakorlatban a fluoreszcens in situ hibridizáció segítségével történik.

\section{Esetismertetés}

\section{Első beteg}

V/4. graviditásból, a 38. gesztációs hétre, kielégítő általános állapotban született. A terhességi anamnézisből polyhydramnion és a magzat kétoldali pyelectasiája emlí-

1. táblázat |A 22q11 kromoszóma deletiós szindróma klinikai tünetei

\begin{tabular}{l}
\hline Magzati fenotípus \\
\hline Szívfejlődési rendellenesség, fóleg kiáramlásipálya-defektusok. \\
Thymuseltérések. \\
Húgyúti rendellenességek. \\
Velőcső-záródási rendellenességek. \\
Polyhydramnion. \\
\hline Újszülött- és gyermekkori fenotípus
\end{tabular}

Arcdysmorphia: hosszúkás arc, arcközép-hypoplasia, hypertelorismus, széles orrgyök, széles orrnyereg, kis száj, kis mandibula, alacsonyan ülő fülek.

Szívfejlődési rendellenesség.

Lágyszájpad-elégtelenség: hypernasalis beszéd, regurgitatio.

Mellékpajzsmirigy-alulmúködés.

Visszatérő fertőzések.

Neuropszichológiai problémák.

Vesebetegségek: agenesis, obstruktív uropathiák, vesicoureteralis reflux.

Szemészeti eltérések: strabismus, strukturális eltérések.

Csontrendszeri eltérések.

Gége-rendellenességek.

Fogászati problémák: ínyhypoplasia, krónikus szuvasodás.

Autoimmun betegségek.

Endokrin betegségek.

\section{Felnött fenotipus}

Típusos arckarakter.

Pszichiátriai betegségek, például szkizofrénia

Szívfejlődési rendellenesség.

Hypernasalis hang.

Mellékpajzsmirigy-alulmúködés

Korai kezdetű Parkinson-kór 
tendő. A családi anamnézisből kiemelendő, hogy az apai nagymamát szkizofréniával, betegünk fiútestvérét rachitis miatt kezelik. Megszületést követően már észlelték minor anomáliáit, feltűnő volt gyenge, rekedtes sírása. A kétoldali pyelectasiát a postnatalis ultrahangvizsgálat megerősítette, nefrológiai gondozásba került. Lábtartási rendellenessége miatt 6 hétig gipszcsizmát hordott. Gerinc-röntgenvizsgálaton L5-S1 spina bifida ábrázolódott. Három hónapos korában gyenge, rekedtes sírás miatt gégetükrözés történt, amely a gége strukturális eltérését nem igazolta. Csecsemőkorában visszatérő felső légúti hurut, pneumonia, lázas húgyúti infekciók miatt ismételten hospitalizálták. Kivizsgálása során jobb oldali IV-V. stádiumú vesicoureteralis reflux igazolódott, amely miatt két alkalommal injektáló kezelés, majd ureter-neoimplantáció történt. Immunológiai kivizsgálása során alacsony IgG-érték és T-lymphocyta-szám igazolódott. Kardiológiai, audiológiai és szemészeti vizsgálata nem mutatott ki kóros eltérést.

A jelenleg 5 éves kisfiú óvodába jár, szobatiszta, gyógycipőt és rögzítősínt hord a bal lábán, rendszeresen szed vizeletfertőtlenítőt, $\mathrm{D}_{3}$-vitamint és kalciumot. Megkésett pszichomotoros fejlődés, elsősorban a beszédfejlődés késése miatt intenzív gyógypedagógiai, logopédiai fejlesztésben részesül. Dysmorphologia státusából kiemelendő a kis mandibula, mélyen ülő szemek, alacsonyan ülő, hátrarotált fülek, előreálló philtrum, keskeny felsőajak, hosszú ujjak, alacsonyan inzertált hüvelykujjak, lecsapott vállak, ellapult lábboltozat.

Újszülöttkorától nyomon követtük genetikai tanácsadónkban, az eddig elvégzett vizsgálatok során rutinkromoszómavizsgálata, a 4p- és az 5p-szindrómák célzott FISH-vizsgálata, a cisztás fibrosis öt leggyakoribb mutációanalízise és a szérumtranszferrin izoelektromos fokuszálás vizsgálata kórjelzőt nem mutattak.

\section{Második beteg}

I/1. graviditásból, a 38. gesztációs hétre császármetszéssel, 2550 g-mal született. Az intrauterin észlelt szív- és vesefejlődési rendellenesség (kettős kiáramlású jobb kamra, jobb oldali hypoplasiás vese) miatt elvégzett magzati kromoszómavizsgálat normális eredményt adott. Családi anamnéziséből kiemelendő, hogy az édesapa myasthenia gravis miatt áll gondozás alatt, az édesanyát pedig korábban epilepszia miatt kezelték. Megszületést követően a vitium korrekciója megtörtént. A kislányt 3 éves korában vizsgáltuk először genetikai tanácsadásunkon. A dystrophiás gyermekre besüppedt orrgyök, hypertelorismus, hosszú phyltrum, gótikus szájpad, alacsonyan ülő, kis fülek, ízületi lazaság, előrehelyezett végbélnyílás, carieses fogazat volt jellemző. A jobb oldali szaruhártyahomály hátterében Peter's anomália igazolódott, emiatt 4 éves korában szaruhártya-átültetésen esett át. Kissé megkésett mozgás- és beszédfejlődés miatt ko- rai fejlesztésben, visuscsökkenés miatt látásfejlesztésben részesült. Jelenleg 9 éves, általános iskolába jár, kardiológiai és nefrológiai szempontból kompenzált. Tünetei hátterében felmerült Kabuki-szindróma - csak külföldön elvégezhető, molekuláris genetikai vizsgálatára nem került sor.

Tekintettel a minor anomáliákra és a többszörös fejlődési rendellenességre - genomiális betegségre gyanakodva - mindkét betegünk mintáit megvizsgáltuk array komparatív genomhibridizáció segítségével is.

\section{Array komparatív genomhibridizáció $(\mathrm{aCGH})$}

Az aCGH-módszerhez az Agilent nagy felbontású, Human Genome G3 Sureprint 8x60K ISCA v2 oligonukleotidalapú microarray-t (Agilent Technologies, Amerikai Egyesült Államok) használtuk, amely 55077 próbát tartalmaz (átlagos próbatávolság $60 \mathrm{~kb}$, az ISCA régiókban kisebb). A DNS-izoláláshoz a NucleoSpin ${ }^{\circledR}$ Dx Blood kitet használtuk (Macherey-Nagel, Düren) a gyártó előírásai szerint. A minták jelölése és a hibridizáció során az Agilent-protokoll szerint jártunk el (Agilent Oligonucleotide Array-Based CGH for Genomic DNA Analysis Enzymatic Labeling Protocol v7.2; July 2012). Röviden összefoglalva: $500 \mathrm{ng}$ mennyiséget használtunk a vizsgált betegektől származó és a nemüknek megfelelő kontroll-DNS-mintákból (Promega Male/Female Reference DNA, Amerikai Egyesült Államok) egyaránt. A DNS-t AluI és RsaI restrikciós endonukleázok segítségével végzett kettős emésztéssel fragmentáltuk (Promega, Amerikai Egyesült Államok). Az emésztett DNS-t random primingmódszerrel jelöltük az Agilent Genomic DNA Labeling Kit (SureTag Complete DNA Labeling Kit, Agilent, Amerikai Egyesült Államok) alkalmazásával. A jelölt fragmenseket Amicon Ultra AU-30 filterekkel tisztítottuk meg (Merck Millipore, Amerikai Egyesült Államok). A beteg- és a kontrollmintákat $50 \mu \mathrm{g}$ Human Cot-1 DNS jelenlétében hibridizáltuk a microarray felületén $65^{\circ} \mathrm{C}$-on 24 órán át. A hibridizációt követő mosási lépéseket az Agilent Protocol v7.2 ajánlásainak megfelelően végeztük. Az elkészült array-t a G2565CA szkenner (Agilent Technologies, California, Amerikai Egyesült Államok) és az Agilent Feature Extraction szoftver (v10.10.1.1.) segítségével analizáltuk. Az eredményeket az Agilent Cytogenomics szoftverrel (v2.9) értékeltük. A DNS-szekvenciára vonatkozó információ a UCSC adatbázisnak megfelelő (Human Genome Browser, Feb 2009 Assembly; GRCh37:hg19).

Az aCGH-vizsgálat során az 1. betegnél a 22-es kromoszóma 22q11.21 régiójában egy 1,034 Mb és egy 1,775 Mb méretü deletiót, míg a 2. betegnél a 22-es kromoszóma $22 q 11.21$ régiójában egy $2,610 \mathrm{Mb}$ méretü deletiót mutattunk ki. 


\section{Fluoreszcens in situ hibridizáció (FISH)}

$\mathrm{Az}$ aCGH-módszerrel kimutatott deletiót metafázisFISH segítségével konfirmáltuk, amihez a 22q11.2 (LSI N25) kromoszomális régióra (Di George-szindróma-régió), valamint kontrollként a 22q13 (LSI ARSA) régióra specifikus fluoreszcens jelölésü próbákat használtuk (Vysis, Abbott Laboratories, Abbott Park, Illinois, Amerikai Egyesült Államok). A metafázis-FISH-vizsgálattal mindkét betegnél kimutathatóak voltak az array CGH-módszerrel kimutatott deletiók. A 2. beteg szüleinek mintái azonos FISH-próbával vizsgálva a 22q11.21 régióban nem igazoltak deletiót.

\section{Megbeszélés}

Mindkét betegünk nagyon különbözött a klasszikus, Angelo M. Di George által 1965-ben leírt, majd róla elnevezett szindrómától [8]. A fó tünet ott a thymus és a mellékpajzsmirigy veleszületett hiánya volt, a klasszikus fenotípus később szívfejlődési rendellenességgel egészült ki. Amióta ismert, hogy a klasszikustól igen különböző fenotípusú betegekben is ugyanaz a genetikai eltérés, a 22q11.2 deletiója mutatható ki, próbálkozások történtek a nómenklatúra egységesítésére. A CATCH-22, a 22-es csapdája jól kifejezi diagnosztikai problémáinkat. A 22q11 kromoszóma deletiós szindróma a leggyakoribb microdeletiós szindróma, klinikai tünetei időnként csak diszkrétek ugyan, de olyan szerteágazóak lehetnek, hogy az orvoslás szinte minden szubspecialitását érinthetik. Eddig csak akkor tudtuk diagnosztizálni, ha gondoltunk rá. Az 1. betegünknél a szívfejlődési rendellenesség hiánya, a 2. esetben pedig a nem teljesen jellegzetes dysmorphologia és a klinikai képet meghatározó szemfejlődési rendellenesség más irányba terelte a klinikai genetikus gondolkodását.

Intézetünkben, a Pécsi Tudományegyetem Orvosi Genetikai Intézetében 2012-ben kezdődött meg az array komparatív genomhibridizáció módszer beállítása. Az új molekuláris citogenetikai módszer alkalmazásának első célcsoportja olyan komplex fejlődési rendellenességben szenvedő betegek vizsgálata volt, akiknél hagyományos citogenetikai módszerekkel nem sikerült alátámasztani a fenotípus genetikai hátterét. Első eredményeinkről az Orvosi Hetilap korábbi számában számoltunk be [9]. Így kerülhetett sor az ismertetett két beteg mintáinak aCGH-vizsgálatára, a 22-es kromoszóma hosszú karján lévő kritikus régió microdeletiójának kimutatására. A deletio konfirmálása mindkét betegünknél FISH-vizsgálattal történt, ami alátámasztotta a diagnózist. Az 1. beteg szülei nem egyeztek bele további vizsgálatokba, pedig a családi anamnézisben szereplő kalciumanyagcsere-zavar és szkizofrénia miatt ez indokolt lehet. A 2. beteg szüleinél elvégzett negatív FISH-vizsgálat a gyermekben kimutatott deletio de novo eredetét támasztotta alá.

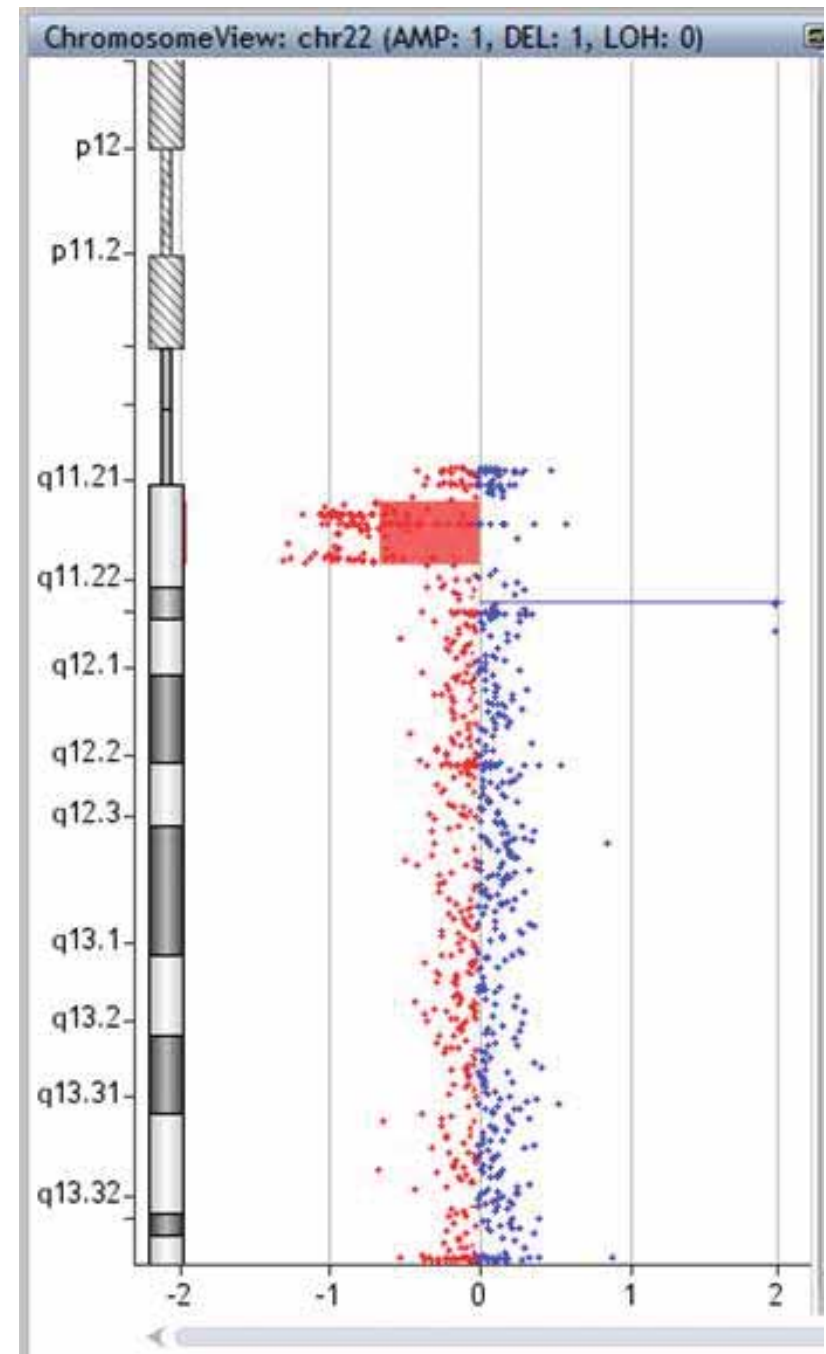

\begin{tabular}{l|l} 
1. ábra & $\begin{array}{l}\text { A 2. beteg aCGH-vizsgálatának eredménye. A 22q11.21 régiót } \\
\text { érintő deletio piros színnel kiemelve látható }\end{array}$
\end{tabular}

Korábbi eredményeink és a fentiek alapján úgy gondoljuk, hogy az array komparatív genomhibridizáció megfelelő diagnosztikai módszer lehet többszörös fejlődési rendellenességek esetén genomiális eltérések kimutatására.

Anyagi támogatás: A közlemény megírása anyagi támogatásban nem részesült.

Szerzői munkamegosztás: T. Á.: Klinikai betegvizsgálat, a kézirat szövegezése. H. K.: Klinikai betegvizsgálat, a kézirat javítása és kiegészítése. L-F. Á.: Klinikai betegvizsgálat. C. M.: A módszer leírása. D. B. Az array CGH vizsgálatok végzése (C. M. vezetésével). M. B.: A kézirat javítása és kiegészítése.

A cikk végleges változatát valamennyi szerző elolvasta és jóváhagyta.

Érdekeltségek: A szerzőknek nincsenek érdekeltségeik. 


\section{Irodalom}

[1] McDonald-McGinn, D. M., Sullivan, K. E.: Chromosome $22 \mathrm{q} 11.2$ deletion syndrome (DiGeorge syndrome/Velocardiofacial syndrome). Medicine (Baltimore), 2011, 90(1), 1-18.

[2] Kobrynski, L. J., Sullivan, K. E.: Velocardiofacial syndrome, DiGeorge syndrome: the chromosome $22 \mathrm{q} 11.2$ deletion syndromes. Lancet, 2007, 370(9596), 1443-1452.

[3] Botto, L. D., May, K., Fernhoff, P. M., et al.: A population-based study of the 22q11.2 deletion: phenotype, incidence, and contribution to major birth defects in the population. Pediatrics, 2003, 112(1), 101-107.

[4] Vogels, A., Schevenels, S., Cayenberghs, R., et al: Presenting symptoms in adults with the $22 \mathrm{ql} 1$ deletion syndrome. Eur. J. Med. Genet., 2014, 57(4), 157-162.

[5] Emanuel, B. S.: Molecular mechanisms and diagnosis of chromosome 22q11.2 rearrangements. Dev. Disabil. Res. Rev., 2008, 14(1), 11-18.
[6] Gao, S., Li, X., Amendt, B. A.: Understanding the role of Tbxl as a candidate gene for $22 \mathrm{q} 11.2$ deletion syndrome. Curr. Allergy Asthma Rep., 2013, 13(6), 613-621.

[7] Hacihamdioğlu, B., Hacibamdioğlu, D., Delil, K., et al.: 22ql1 deletion syndrome: current perspective. Appl. Clin. Gen., 2015, $8,123-132$.

[8] DiGeorge, A. M.: Discussions on a new concept of the cellular basis of immunology. J. Pediatr., 1965, 67(5), 907-908.

[9] Duga, B., Czakó, M., Hadzsiev, K., et al.: Identifying rare genomic disorders with array comparative genomic hybridization in Hungary. [Ritka genomikai betegségek azonosítása array komparatív genomhibridizációs módszerrel - elsőként Magyarországon.] Orv. Hetil., 2014, 155(9), 358-361. [Hungarian]

(Till Ágnes dr., Pécs, József A. u. 7., 7623 e-mail: till.agnes@pte.hu)

\section{A rendezvények és kongresszusok híranyagának leadása}

a lap megjelenése előtt legalább 40 nappal lehetséges, a 6 hetes nyomdai átfutás miatt. Kérjük megrendelőink szíves megértését.

A híranyagokat a következő címre kérjük: Orvosi Hetilap titkársága: Budai.Edit@akkrt.hu Akadémiai Kiadó Zrt. 